(4) Biological investigations have been carried out by Dr. Paul S. Galtsoff and Dr. F. G. Walton Smith. Fungus-like filaments, first observed early in March by Dr. Galtsoff, have been found constantly in all diseased sponge tissues examined. The filaments have not been found in healthy sponge tissues, nor in the remains of sponges which have been long dead. They are particularly abundant in the marginal zone between the newly dead and living tissues of diseased sponges. The infection spreads gradually through the tissues, starting often from an origin inside. The symptoms contrast with those observed when death has ensued from other known factors observed during the previous two and a half years. The infection of the micro-organism and the mortality are confined only to a few species of sponge (including unfortunately all the six commercial species), and have not been observed to affect any other form of marine life.

It has been possible to infect Reef and Wool sponge with the filaments, by contact with fragments of infected sponges of the same species.

Attempts are being made to have the organism isolated and identified. A full account of this and further projected work will be published elsewhere.

United States Bureau of Fisheries, Paul S. Galtsoff. Washington, D.C.

Hubert H. Brown.

C. Leslie Smith.

F. G. Walton Smith.

Sponge Fishery Investigations,

Nassau, N.P., Bahamas.

$$
\text { April } 1 .
$$

“Papers from the Tortugas Laboratory", 5, 7-45 (1914).

\section{Growth of Borrelia duttoni in the Developing Chicken Embryo}

The value of the developing egg in the study of many viruses is now well established, and the chicken embryo method of passage has proved of great use in propagating these viruses, which, as a rule, can only be grown in tissue culture, and not in the ordinary bacteriological culture media. Many members of the spirochætal class of organism can only be grown, with great difficulty, in special media, and it was therefore decided to attempt the growth of a spirochæte in the developing chicken embryo.

The organism chosen was that responsible for African relapsing fever, Borrelia duttoni, for this cannot readily be grown in culture, but is usually maintained by passage from mouse to mouse.

The method was simply the inoculation of a fertile hen's egg, which had been incubated for a certain period, usually eight to twelve days, at the temperature customary for such incubation, namely, $38 \cdot 5^{\circ} \mathrm{C}$. After this preliminary period, which was necessary to ensure that the embryo inside was at a suitable stage of development, the egg was inoculated with a small amount of mouse blood, the mouse having been infected a few days previously with the spirochæte of relapsing fever. Having introduced the inoculum into the egg, the site of inoculation was sealed off with sterile paraffin, and the egg now incubated for a further interval of three to four days, at the ordinary bacteriological temperature, that is, $37 \cdot 0^{\circ} \mathrm{C}$. At the end of this time, the egg was opened and the contents examined by microscopical and other methods.
When such an egg was opened and the fluid inside inspected by the dark-ground illumination technique, it was found that many actively motile, living spirochætes were present. These findings were easily confirmed by inoculation of the material into mice, for on examining the mice forty-eight hours later, it was found that their blood contained large numbers of the organism.

A second batch of eggs, after preliminary incubation, was then inoculated with the material from the first eggs, and again, after three days further incubation, these were found to contain living spirochætes, both by visual examination and by mouse inoculation.

The process of egg passage was then continued and a third sample of developing eggs, this time only seven days old, was infected with a small drop of the fluid from the second passage ones, and these, on being inspected by the dark-field method, showed a very large number of spirochætes to be present, particularly in the blood of the embryo, with a very much smaller number in the rest of the egg contents. Animal inoculation again proved that these spirochætes had not lost their pathogenicity towards mice.

A fourth passage experiment gave precisely similar results.

Further work is in progress, with the view of determining the effect of continued egg passage on the characters of the spirochæte concerned.

It is interesting to note here the effect of the spirochæte on the embryo. If viruses are grown in eggs, the usual action is either to kill the embryo, or, alternatively, to produce local lesions on the chorioallantoic membrane, with little or no effect on the embryo. Borrelia duttoni, however, has a different action, for in the four passages described above no naked-eye change could be observed in the membrane nor was the embryo killed. Examination of the constituent parts of several eggs appeared to show that the lesion produced took the form of a blood invasion. This finding is similar to the result produced in man and susceptible animals, for in them there is a definite infection of the blood stream, easily demonstrated, as a rule, by blood films.

Since writing the above, my attention has been directed to the work of Morrow and his colleagues ${ }^{1}$, who have cultivated Leptospira icterohomorrhagice on the chorio-allantoic membrane.

Department of Bacteriology,

University of Edinburgh. April 11.

${ }^{1}$ Science, 88, 384 (1938).

R. KNIGHT OAG.

\section{Genetic and Cytological Interference}

PAIRED meiotic chromosomes may have their four chromatids or strands involved in a variety of ways in two adjacent chiasmata. In most studies of chiasmata the materials have not been favourable enough to permit the tracing of all four strands through two or more chiasmata. We have recently been able to do this in forty-eight complete pollen mother cells of Trillium erectum, and have observed therein eight types of chiasma pairs. These are shown diagrammatically in Fig. 1 together with their frequencies and interstitial lengths (alternative oneplane representations of these three-dimensional configurations are here neglected).

Clear separation of chromatids and reduction of coiling at metaphase may be obtained in Trillium 